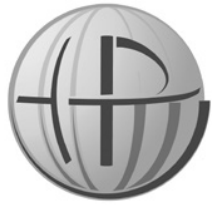

Horyzonty Polityki 2020, Vol. 11, No 37

\section{Magdalena ZajączKowsKa}

http://orcid.org/0000-0001-7449-8698 Uniwersytet Ekonomiczny w Krakowie Instytut Ekonomii Katedra Studiów Europejskich i Integracji Gospodarczej zajaczkm@uek.krakow.pl

DOI: $10.35765 / H P .1906$

OPEN ACCESS

\title{
Odnawialne źródła energii a bezpieczeństwo energetyczne Polski. Wybrane aspekty
}

\section{Streszczenie}

CEL NAUKOWY: Podstawowym celem artykułu jest przedstawienie wyników badań dotyczących określenia wpływu czynników mikroekonomicznych (energetyki prosumenckiej) na stan bezpieczeństwa energetycznego Polski w kontekście odnawialnych źródeł energii.

PROBLEM I METODY B ADAWCZE: Zagadnienie bezpieczeństwa energetycznego $\mathrm{w}$ Polsce jest przedmiotem przede wszystkim debaty w sferze politologicznej. Większość analiz ekonomicznych (ekonomia bezpieczeństwa energetycznego) uwzględnia głównie aspekty makroekonomiczne, pomijając rolę i znaczenie szybko rozwijającego się sektora odnawialnych źródeł energii i przede wszystkim szybko rozwijającej się energetyki rozproszonej (perspektywa mikroekonomiczna). W celu sprostania postawionemu problemowi badawczemu wykorzystano metody badawcze uwzględniające analizę literatury przedmiotu, metody statystyki opisowej oraz metody tabelaryczno-opisowe i wykresy wraz z syntezą wniosków.

PROCES WYWODU: W pierwszej kolejności przedstawione zostaną wyniki przeglądu debaty na temat definiowania pojęcia bezpieczeństwa energetycznego, w drugiej - najważniejsze miary i determinanty tegoż bezpieczeństwa, a w trzeciej - efekty analizy rozwoju energetyki rozproszonej w kontekście odnawialnych źródła energii jako elementu bezpieczeństwa energetycznego Polski.

WYNIKI ANALIZY NAUKOWEJ: Przeprowadzona analiza prowadzi do wniosku, że sektor energetyki rozproszonej stanowi istotny element sektora 
odnawianych źródeł energii, a przez to może stanowić istotny czynnik bezpieczeństwa energetycznego Polski.

WNIOSKI, INNOWACJE, REKOMENDACJE: Omawiana problematyka jest istotna, nie traci na znaczeniu, a najbliższe lata przyniosą intensyfikację badań w tym obszarze. Wnioski płynące z przeprowadzonych badań adresowane są zarówno do politologów, decydentów politycznych, jak i ekonomistów odpowiedzialnych za wdrażanie polityki klimatyczno-energetycznej, w tym sektora odnawialnych źródeł energii.

\section{SŁOWA KLUCZOWE:}

bezpieczeństwo energetyczne, energetyka rozproszona, odnawialne źródła energii, prosument

\section{Abstract}

\section{RENEWABLE ENERGY SOURCES AND POLAND'S ENERGY SECURITY.SELECTED ASPECTS}

RESEARCHE OBJECTIVE: The main aim of the article is to present the results of research on the impact of microeconomic factors (prosumer energy) on the state of Poland's energy security in the context of renewable energy sources.

THE RESEARCH PROBLEM AND METHODS: Energy security in Poland is primarily the subject of a debate in the political science sphere. Most economic analyzes (energy security economics) take into account, first of all, macroeconomic aspects, ignoring the role and importance of the rapidly developing renewable energy sector and, above all, the rapidly developing distributed energy (microeconomic perspective). In order to meet the research problem posed, research methods were used, taking into account the analysis of the literature on the subject, methods of descriptive statistics as well as tabular and descriptive methods and graphs with a synthesis of conclusions.

THE PROCESS OF ARGUMENTATION: First of all, the results of the review of the debate on the definition of the concept of energy security will be presented, secondly, the most important measures and determinants of this security, and in the third place, the effects of the analysis of the development of distributed energy in the context of renewable energy sources as an element of Poland's energy security.

RESEARCH RESULTS: The conducted analysis leads to the conclusion that the distributed energy sector is an important element of the sector of renewable energy sources and therefore it may constitute a significant factor of Poland's energy security. 
CONCLUSIONS, INNOVATIONS, AND RECOMMENDATIONS: The discussed issue is important, it does not lose its importance, and the coming years will bring intensification of research in this area. The conclusions of the research are addressed to both political scientists, political decision makers and economists responsible for implementing climate and energy policy; including the renewable energy sector.

\section{KeYwORDS:}

distributed energy, energy security, prosumer, renewable energy sources

\section{WSTĘP}

W ostatnich latach zagadnienie bezpieczeństwa energetycznego jest przedmiotem wielu badań, debat i dyskusji. Z uwagi na liczne determinanty wpływające na jego zagwarantowanie dyskurs ma charakter interdyscyplinarny i jest prowadzony na wielu płaszczyznach. Niewątpliwie do rozwoju dyskusji przyczyniła się sytuacja międzynarodowa (negocjacje klimatyczno-energetyczne), jak i działania Unii Europejskiej w ramach ciągłego rozwoju polityki klimatyczno-energetycznej UE. Równocześnie debata dotycząca miar oraz determinant bezpieczeństwa energetycznego stale się toczy i jest podejmowana przez szerokie grono zarówno politologów, ekonomistów, jak i socjologów. Przyjęte w ostatnich latach w Polsce rozwiązania prawne oraz uruchomienie rządowych programów wsparcia rozwoju mikroinstalacji i energetyki prosumenckiej doprowadziły do szybkiego rozwoju tego sektora, który stał się jednocześnie istotnym elementem rozwoju odnawialnych źródeł energii.

Podstawowym celem artykułu jest przedstawienie wyników analizy roli i znaczenia energetyki rozproszonej, będącej częścią sektora odnawialnych źródeł energii w zagwarantowaniu bezpieczeństwa energetycznego Polski. 


\section{DEFINIOWANIE BEZPIECZEŃSTWA ENERGETYCZNEGO}

Debata dotycząca bezpieczeństwa energetycznego jest prowadzona $\mathrm{w}$ literaturze przedmiotu od wielu lat. W ostatnim okresie zyskała jednak na znaczeniu w związku z sytuacją międzynarodowa, a mianowicie negocjacjami klimatycznymi w skali globalnej oraz szybkim rozwojem polityki klimatyczno-energetycznej UE. Początkowo koncentrowała się na bezpieczeństwie dostaw, ze szczególnym naciskiem na aspekty polityczne. Z czasem do debaty włączono zagadnienia ekonomiczne, co obecnie jest przedmiotem szczególnego zainteresowania badaczy.

Należy w związku z tym podkreślić, że katalog definicji bezpieczeństwa energetycznego przedstawiany w literaturze przedmiotu jest szeroki. Nie występuje jedna uniwersalna definicja, ponieważ postrzeganie tego zjawiska zależy od perspektywy podmiotu, który bierze udział w globalnym rynku energii. Inaczej jest ono postrzegane w perspektywie krótkoterminowej (ryzyko wstrzymania dostaw nośników energii przez głównych producentów, co może być szczególnie dotkliwe dla gospodarek silnie uzależnionych od importu tychże nośników), a inaczej w ujęciu długookresowym (wyczerpywanie się zasobów czy zmiany w poziomie cen surowców). Odmienne podejście proponowane jest również $\mathrm{w}$ związku $\mathrm{z}$ tworzeniem strategii w ramach różnych polityk publicznych, mających zagwarantować bezpieczeństwo energetyczne kraju. W kontekście narzędzi służących zapewnieniu bezpieczeństwa energetycznego inaczej będzie więc ono definiowane przez ekonomistów, a inaczej przez politologów (Molo, 2013). Skupiając się na aspektach ekonomicznych należy zwrócić uwagę na podstawowy element, jakim jest cena, jej poziom oraz czynniki na nią wpływające. W związku z tym bezpieczeństwo energetyczne definiuje się jako dostępność źródeł energii w każdym czasie, mogących pochodzić z różnych źródeł, zgodnie z zapotrzebowaniem na energię z tychże źródeł oraz w odpowiednich ilościach zabezpieczających deklarowany popyt. Nieodłącznym elementem bezpieczeństwa energetycznego jest poziom cen, które muszą kształtować się na poziomie gwarantującym normalną konsumpcję energii przez odbiorców finalnych (Żukrowska, 2011). Definicja ta stara się więc uwzględnić zarówno aspekty podażowe, 
jak i popytowe, koncentrując się na ujęciu bezpieczeństwa energetycznego w kategoriach stanu bez położenia nacisku na rozumienie bezpieczeństwa energetycznego jako procesu jego zapewnienia, w tym bez uwzględnienia roli podmiotów, które przez swoje decyzje mogą wpływać na ten proces.

Warto również zwrócić uwagę na inne ujęcie biorące pod uwagę rolę wymiarów bezpieczeństwa energetycznego: wewnętrznego i zewnętrznego. Pierwszy z nich związany jest ze ścieraniem się popytu i podaży energii, jej oddziaływaniem na środowisko naturalne, zaspokajaniem potrzeb konsumentów oraz obowiązującymi regulacjami prawnymi. W wymiarze zewnętrznym podkreśla się natomiast możliwość uzupełnienia niedoboru energii lub zagospodarowania jej nadmiaru, która może pojawić się w wyniku rozbieżności między krajowym zapotrzebowaniem a produkcją (Czerpak, 2006).

Ponadto, podejmując próbę zdefiniowania bezpieczeństwa energetycznego oraz umiejscowienia tego pojęcia w naukach społeczno-ekonomicznych, poszerza się wyżej wymienione wymiary o następujące (Barcik, 2008):

- polityczny - związany z politycznym uwarunkowaniem stosunków międzynarodowych,

- gospodarczy - dotyczący zwłaszcza bezpieczeństwa energetycznego,

- społeczny - określany jako zdolność do utrzymania swych podstawowych atrybutów, np. kultura, język, religia,

- wojskowy - obejmujący kwestie militarne,

- ekologiczny - opierający swoje założenia na potencjalnie destruktywnym wpływie degradacji środowiska na bezpieczeństwo ludności.

Coraz częściej nieodłącznym elementem definicji bezpieczeństwa energetycznego jest uwzględnianie w nich jego elementów, które w opinii autorki należy jednakże określić wprost jako czynniki determinujące poziom bezpieczeństwa energetycznego, kształtujące go i tym samym decydujące o jego zagwarantowaniu lub nie. Do tychże tradycyjnych elementów bezpieczeństwa energetycznego zalicza się: centra popytu, źródła dostaw, geopolitykę, strukturę rynku oraz instytucje. Najprościej i najczęściej bezpieczeństwo energetyczne jest rozumiane jako bezpieczeństwo dostaw (energii) (Dziedzic, 2011). 
$\mathrm{Z}$ uwagi na rosnącą rolę i znaczenie energii w systemach gospodarczych poszczególnych państw, konieczność zagwarantowania bezpieczeństwa energetycznego jest coraz częściej rozpatrywana jako element bezpieczeństwa gospodarczego państwa, zwanego również bezpieczeństwem ekonomicznym, a przez to bezpieczeństwa narodowego.

Bezpieczeństwo ekonomiczne jest gwarantem prawidłowego przebiegu procesów gospodarczych w państwie. Są to sytuacje, w których gospodarka może rozwijać się prawidłowo, generować zyski, zwiększać oszczędności czy minimalizować zagrożenia zewnętrzne przyczyniające się do zakłócenia prawidłowego działania gospodarki (Księżopolski, 2004). Jest to także możliwość ciągłego rozwoju gospodarki państwa oraz jego wszystkich instrumentów przy zachowaniu wysokiego poziomu życia ludności oraz należytego miejsca na arenie międzynarodowej (Zięba, 2004).

Bezpieczeństwo energetyczne $w$ aspekcie ekonomicznym ( $w$ kontekście finansów publicznych) jest więc zaliczane do klasycznych dóbr publicznych, a za jego zapewnienie odpowiadają władze państwowe. Realizując poszczególne polityki publiczne wykorzystuje się szeroki zakres narzędzi i instytucji, z pominięciem mechanizmów rynkowych typowych dla dóbr prywatnych. Organy władzy państwowej mają możliwość regulowania kwestii związanych z produkcją dystrybucją i dostarczaniem energii w kraju. Pomimo tego, że pewne fazy mogą i są powierzane podmiotom sektora prywatnego, to na władzy publicznej ciąży obowiązek prowadzenia odpowiedniej polityki energetycznej, gwarantującej bezpieczeństwo dostaw energii (Braun, 2018).

Z punktu widzenia dalszych rozważań, słuszne wydaje się ujęcie bezpieczeństwa jako wielowymiarowego stanu, w jakim interesy danego podmiotu nie są zagrożone, oraz aktywne, wielorakie działania na rzecz zapewnienia takiego stanu (Barcik, 2008).

Zawarta $\mathrm{w}$ prawie polskim definicja bezpieczeństwa energetycznego określa go jako „stan gospodarki, umożliwiający pokrycie bieżącego i perspektywicznego zapotrzebowania odbiorców na paliwa i energię w sposób technicznie i ekonomicznie uzasadniony, przy zachowaniu wymagań ochrony środowiska" (Ustawa, 1997). W ustawie o zapasach ropy naftowej, produktów naftowych i gazu ziemnego oraz zasadach postępowania w sytuacjach zagrożenia bezpieczeństwa paliwowego państwa i zakłóceń na rynku państwowym, 
bezpieczeństwo energetyczne jest określane jako bezpieczeństwo surowcowo-paliwowe. Jest to sytuacja, w której aktualne zapotrzebowanie na surowce energetyczne jest zaspokajane w odpowiednim czasie, po odpowiedniej cenie oraz przy zachowaniu odpowiedniej jakości surowców (Ustawa, 2007). Obie definicje zawierają trzy aspekty: ekologiczny, geopolityczny oraz ekonomiczny, które są wspólne dla unijnych definicji bezpieczeństwa energetycznego. Ustawodawca zwraca także uwagę na takie kwestie, jak usprawnienie pozyskiwania energii oraz zwiększenie jej wydajności dzięki nowym technologiom. Natomiast nie ujęto w nich samowystarczalności oraz suwerenności politycznej (Kuciński, 2006).

Warto również zwrócić uwagę na definicję bezpieczeństwa energetycznego zawartą w projekcie „Polityka energetyczna Polski do 2040" (Ministerstwo Aktywów Państwowych, 2019b), która jest zbieżna z definicją już obowiązującą:

Bezpieczeństwo energetyczne oznacza aktualne i przyszłe zaspokojenie potrzeb odbiorców na paliwa i energię w sposób technicznie i ekonomicznie uzasadniony, przy zachowaniu wymagań ochrony środowiska. Oznacza to obecne i perspektywiczne zagwarantowanie bezpieczeństwa dostaw surowców, wytwarzania, przesyłu i dystrybucji, czyli pełnego łańcucha energetycznego.

\section{MIARY ORAZ DETERMINANTY BEZPIECZEŃSTWA ENERGETYCZNEGO}

$\mathrm{Z}$ uwagi na rosnącą rolę i znaczenie energii $\mathrm{w}$ systemach gospodarczych poszczególnych państw, konieczność zagwarantowania bezpieczeństwa energetycznego jest coraz częściej rozpatrywana jako element bezpieczeństwa gospodarczego państwa, a przez to bezpieczeństwa narodowego.

Bezpieczeństwo energetyczne, tak jak próbowano wykazać w powyższych rozważaniach dotyczących prób stworzenia jednolitej definicji, jest zjawiskiem złożonym, charakteryzującym się kompleksowością. Na jego zagwarantowanie ma wpływ szereg determinant, a podejmowane decyzje $\mathrm{w}$ tej sferze mają charakter strategiczny i polityczny oraz rodzą poważne konsekwencje dla całej gospodarki i społeczeństwa. 
W badaniach nad bezpieczeństwem energetycznym zaproponowano kilka sposobów jego mierzenia. Po pierwsze, może się ono odbywać za pomocą modeli przedstawiających zmiany PKB w wyniku zakłóceń występujących $\mathrm{w}$ dostawach energii. Jednym $\mathrm{z}$ takich modeli jest tzw. prosty model importu netto Banku Światowego. Miary bezpieczeństwa dostaw opierają się również np. na wskaźnikach koncentracji (np. wskaźniku Herfindahla-Hirschmana) lub rozproszenia (np. wskaźniku Stirlinga). Często miary te są uzupełniane elementami związanymi ze stabilnością geopolityczną dostawcy, jego bazą surowcową lub udziałem paliwa w bilansie energii pierwotnej (Nyga-Łukaszewska, 2016). Kolejną propozycją wykorzystywaną przez Unię Europejską jest mierzenie bezpieczeństwa energetycznego za pomocą wskaźnika zależności energetycznej, która ilustruje, $\mathrm{w}$ jakim stopniu gospodarka krajowa oparta jest na imporcie, w celu zaspokojenia swoich potrzeb energetycznych (Eurostat, 2020).

Przegląd proponowanych w literaturze przedmiotu miar i wskaźników pozwala wyodrębnić katalog determinant, które są rozumiane jako czynniki w istotny sposób wpływające na to bezpieczeństwo. Można je również określić jako uwarunkowania. Przyjmuje się w związku z tym dwa podejścia przy określaniu relacji między tymi pojęciami. Według pierwszego, determinanty uznaje się za szczególnie istotne uwarunkowania, które decydują i przesądzają w kształtowaniu bezpieczeństwa. Drugie podejście zakłada natomiast równorzędne, tożsame traktowanie tych pojęć (Jaźwiński, 2011).

Do najważniejszych elementów kształtujących bezpieczeństwo energetyczne zalicza się (Soroka, 2015): wielkość zasobów nośników energetycznych znajdujących się na terenie danego kraju, stopień zróżnicowania źródeł zaopatrzenia, pochodzenie źródeł zaopatrzenia (krajowe lub zagraniczne), ilość zmagazynowanych rezerw, poziom rozwoju odnawialnych źródeł energii, forma własności przedsiębiorstw sektora energetycznego i systemu zaopatrzenia, stan systemu zaopatrzenia (moc przesyłowa, stan techniczny, niezawodność), poziom rozwoju środków transportu i infrastruktury drogowo-kolejowej, jakość nadzoru państwa nad całością procesu produkcji i dystrybucji energii, jakość panowania i wdrażania w życie decyzji rozwojowych i inwestycyjnych, możliwość finansowania nowych technologii, stabilność sytuacji wewnętrznej czy stabilność sytuacji międzynarodowej. 
Odnawialne źródła energii a bezpieczeństwo energetyczne Polski

W powyższym katalogu warto również uwzględnić możliwości magazynowania paliw na terenie kraju czy liberalizację rynku energii wraz z tworzonymi na nim warunkami konkurencyjności.

\section{ODNAWIALNE ŹRÓDŁA ENERGII ELEMENTEM BEZPIECZEŃSTWA ENERGETYCZNEGO POLSKI}

W 2017 roku w UE udział ropy naftowej i produktów ropopochodnych w produkcji energii wynosił $34,8 \%$, gazu $23,8 \%$, paliw stałych $13,6 \%$, odnawialnych źródeł energii $13,9 \%$, a energii jądrowej $12,6 \%$. Pomimo podjętych w UE w ostatnich kilkunastu latach działaniach wspierających rozwój sektora odnawialnych źródeł energii, unijny sektor energetyczny jest nadal w $48,4 \%$ zależny od paliw kopalnych (European Commission, 2019).

Sytuacja w Polsce kształtuje się odmiennie. Od czasu przejścia z gospodarki centralnie planowanej na gospodarkę wolnorynkową w szeroko rozumianym sektorze energii doszło do daleko idących zmian zarówno od strony modernizacji poszczególnych jednostek wytwórczych i systemu przesyłowego, przez zmiany organizacyjne i prawne, jak i zmianę struktury źródeł energii. Z punktu widzenia funkcjonowania poszczególnych podmiotów gospodarczych najistotniejszą rolę odegrała transformacja w sektorze elektroenergetycznym. Od czasu wprowadzenia przez Unię Europejską kolejnego, bardziej ambitnego pakietu klimatyczno-energetycznego w 2008 roku i zobowiązanie państw członkowskich do przyjęciach ambitnych krajowych celów wpisujących się w cele UE, również w Polsce zmiany w obszarze energetyki znacznie przyspieszyły. Jednym z celów wyznaczonych do osiągnięcia do 2020 roku jest cel dotyczący $20 \%$ udziału odnawialnych źródeł energii w bilansie energetycznym kraju ${ }^{1}$. Na wykresie 1. zaprezentowano udział odnawialnych źródeł energii $\mathrm{w}$ końcowym zużyciu energii brutto $\mathrm{w}$ Polsce $\mathrm{w}$ ostatnich dziecięciu latach, przy uwzględnieniu krajowego planu na rok 2020,

1 Cel ten został zmodyfikowany i podwyższony w perspektywie do 2030 i 2050 roku; w perspektywie 2050 roku UE ma stać się gospodarką zeroemisyjną, a odnawialne źródła energii mają odegrać zasadniczą rolę w realizacji tego planu. 
koniecznego do osiągnięcia w związku ze zobowiązaniami w ramach polityki klimatyczno-energetycznej oraz średniej unijnej.

Wykres 1. Udział energii z odnawialnych źródeł w końcowym zużyciu energii brutto w latach 2008-2018 w Polsce wraz z krajowym celem na rok 2020 i średnią dla UE-28 (w \%)

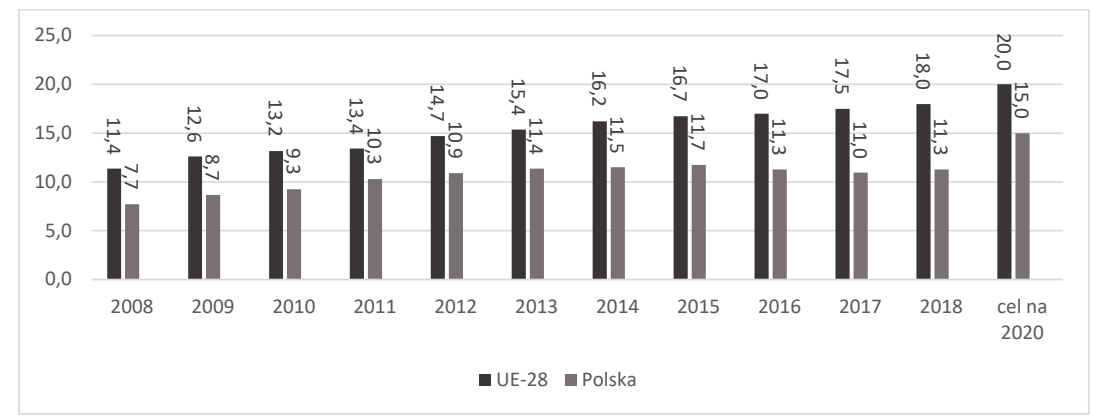

Źródło: opracowanie własne na podstawie: http://ec.europa.eu/eurostat/tgm/ table.do?tab=table\&init=1\&language=en\&pcode=t2020_31\&plugin=1

Analiza danych, przedstawionych na powyższym wykresie, prowadzi do wniosku, że udział odnawialnych źródeł energii w bilansie energetycznym kraju sukcesywnie z roku na rok wzrastał, po czym sektor przestał się rozwijać. Początkowy wzrost (do 2011 r.) podążał śladem wzrostu OZE dla całej UE. Od 2012 roku odnotowano stagnację, z lekkim spadkiem w 2017 roku oraz pogłębiane się dysproporcji między Polską a średnią dla całej UE. Cel wyznaczony na rok 2020 (15\% OZE w miksie energetycznym Polski) nie zostanie osiągnięty. Mając na uwadze pogłębioną analizę ekonomiczną należy podkreślić, że sytuacja energetyczna naszego kraju wydaje się być nadal trudna, ponieważ paliwa kopalne nadal stanowią 52\% w miksie energetycznym kraju. Większość elektrowni i elektrociepłowni dysponuje przestarzałymi blokami energetycznymi, które w przeciągu kilku najbliższych lat powinny zostać wyłączone z eksploatacji ze względu na ich zużycie. Realizacja decyzji o budowie elektrowni jądrowej, jeśli zostanie ostatecznie sfinalizowana, pokryje tylko w niewielkim stopniu potrzeby energetyczne kraju, a wydobycie gazu łupkowego, co do którego pokładano kilka lat temu duże nadzieje, nie nastąpi w najbliższym czasie. Tak więc wszelkie decyzje dotyczące polityki energetycznej kraju będą miały kluczowe znaczenie zarówno dla 
bezpieczeństwa energetycznego Polski, jak i dla dywersyfikacji źródeł energii. Promowanie niewielkich systemów rozproszonych może stać się rozwiązaniem dla dwóch podstawowych problemów systemu energetycznego Polski, tj. konieczności modernizacji elektrowni węglowych oraz wsparcia budowy elektrowni jądrowych.

Należy zwrócić uwagę na rozwiązania prawne, które zostały wprowadzone, po kilku latach prac nad projektem, ustawą z dnia 20 lutego 2015 roku o odnawialnych źródłach energii. Ustawa ta wprowadziła nowe zasady wspierania energii wytwarzanej z takich źródeł. Określa przede wszystkim: zasady i warunki wykonywania działalności w zakresie wytwórczym energii OZE, mechanizmy i instrumenty wspierające wytwarzanie energii elektrycznej, biogazu rolniczego oraz ciepła $w$ instalacjach OZE, zasady wydawania gwarancji pochodzenia energii elektrycznej wytwarzanej z OZE w instalacjach odnawialnego źródła energii, zasady realizacji krajowego planu działania w zakresie energii ze źródeł odnawialnych, warunki i tryb certyfikowania instalatorów mikroinstalacji, małych instalacji i instalacji odnawialnego źródła energii o łącznej mocy zainstalowanej cieplnej nie większej niż $600 \mathrm{~kW}$ oraz akredytowania organizatorów szkoleń, zasady współpracy międzynarodowej w zakresie odnawialnych źródeł energii oraz wspólnych projektów inwestycyjnych (Ustawa, 2015).

Początkowo jedną z podstawowych wprowadzonych zmian była zmiana systemu świadectw pochodzenia energii na system aukcyjny. Rząd decyduje, ile energii odnawialnej potrzebuje, m.in. dla spełnienia celów polityki klimatycznej UE i rozpisuje aukcje, które wygrywa ten, kto zaproponuje najniższą cenę. W zamian dostaje gwarancję wsparcia przez 15 lat. Aukcje są oddzielne dla różnych technologii, dla dużych i małych instalacji.

Bardzo ważnym rozwiązaniem z punktu widzenia wypełnienia unijnego celu oraz zagwarantowania bezpieczeństwa energetycznego Polski było wprowadzenie do ustawy wsparcia rozwoju prosumenckiego wytwarzania prądu. W 2019 roku poszerzono definicję prosumenta, który jest odbiorcą końcowym, wytwarzającym energię elektryczna, za pomocą niewyczerpalnych źródeł, na własne potrzeby, o małych i średnich przedsiębiorców pod warunkiem, że wytwarzanie prądu nie będzie stanowiło głównego przedmiotu działalności tychże podmiotów. Prosument może sprzedawać lub magazynować 
pozyskaną przy użyciu mikroinstalacji energię sprzedawcy, który został do tego zobowiązany na ściśle lub dowolnie uzgodnionych warunkach.

W ustawie przewidziano obowiązek zakupu energii i gwarantowane taryfy na odsprzedaż energii elektrycznej przez prosumentów. Stała cena za prąd ze źródeł do $3 \mathrm{~kW}$ przez 15 lat ma wynosić 75 groszy za kilowatogodzinę energii z hydroenergii, energii wiatrowej i słonecznej. Stała cena energii ma obowiązywać też dla źródeł między $3 \mathrm{~kW}$ a $10 \mathrm{~kW}$ - za jedną kilowatogodzinę energii z biogazu rolniczego - 70 groszy, biogazu ze składowisk - 55 groszy, a z oczyszczalni ścieków -45 groszy. Stała stawka 65 groszy za kilowatogodzinę energii ma obowiązywać dla hydroenergii, energetyki wiatrowej i słonecznej. Dla tych źródeł zapisano również obowiązek zakupu przez 15 lat od oddania instalacji do użytku. Wprowadzenie taryf gwarantowanych ma na celu umożliwienie rozwoju rynkowego danej technologii sektora OZE do momentu, kiedy będzie ona mogła samodzielnie funkcjonować na rynku konkurencyjnym.

Na koniec 2018 roku w Polsce funkcjonowało 54214 mikroinstalacji (wzrost o 235\% względem końca 2016 r.) o łącznej mocy 343 MW (wzrost o 235\% względem końca 2016 r.). Pod koniec 2019 roku liczba prosumentów wyniosła już ok. 149308 (trzykrotny wzrost w porównaniu do 2018 roku). Najszybciej rozwijał się sektor fotowoltaiki: w 2019 roku moc zainstalowana w mikroinstalacjach fotowoltaicznych wynosiła 900 MW (w 2018 r. 344 MW) (Urząd Regulacji Energetyki, 2019).

Do wzrostu mikroinstalacji w Polsce znacząco przyczynił się program dofinansowania mikroinstalacji fotowoltaicznych „Mój Prąd”, zainicjowany w 2. połowie 2019 roku z budżetem 1 mld złotych. Dofinansowanie obejmuje do 50\% kosztów instalacji, wynosi do 5000 zł i jest skierowane do gospodarstw domowych (Ministerstwo Aktywów Państwowych, 2019a).

Wprowadzenie taryf gwarantowanych jest szczególnie istotne dla przydomowych mikroinstalacji odnawialnych źródeł energii, ponieważ w perspektywie mikroekonomicznej jest to szansa dla wielu gospodarstw domowych na zmniejszenie rachunków za energię. Takie rozwiązanie może pozwolić z czasem na poprawę sytuacji wszystkich obywateli oraz stać się istotnym i stabilnym elementem sektora odnawialnych źródeł energii, ponieważ otwiera dostęp do 
rynku produkcji energii w najmniejszych przydomowych źródłach opartych na energii odnawialnej i zmniejsza koszty inwestycji w sieci dystrybucyjne, którym będą obciążani wszyscy użytkownicy energii.

\section{WNIOSKI}

Przegląd literatury przedmiotu prowadzi do wniosku, że nie ma jednolitej i powszechnie akceptowalnej definicji bezpieczeństwa energetycznego, a debata na ten temat nie zakończy się $\mathrm{w}$ najbliższych latach. Mając na uwadze otoczenie makro- i mikroekonomiczne wydaje się jednak, że bardziej utylitarne są propozycje traktowania bezpieczeństwa energetycznego jako procesu, na który wpływa wiele determinant. W ramach rozważań teoretycznych, dotyczących czynników wpływających na kształt i zagwarantowanie bezpieczeństwa energetycznego, większość autorów uwzględnia istotną rolę szeroko rozumianego sektora odnawialnych źródeł energii.

W Polsce, po początkowym okresie szybkiego rozwoju odnawialnych źródeł energii, nastąpiła stagnacja tego sektora. Badania pokazują jednak, że ze względu na coraz niższe koszty instalacji fotowoltaicznych i wsparcie w ramach rządowego programu, liczba zainstalowanych jednostek i mocy osiągnęła rekordowy pułap w 2019 roku, a sektor energetyki rozproszonej, prosumeckiej jest jednym z najszybciej rozwijających się. Należy również zauważyć, że rozwiązania te i wsparcie dla sektora zostały podjęte zbyt późno, aby osiągnąć cel wyznaczony na rok $2020 \mathrm{w}$ ramach polityki klimatyczno-energetycznej UE.

W projekcie „Polityki energetycznej Polski do 2050 roku” Ministerstwo Aktywów Państwowych założyło, że w Polsce nadal podstawowym źródłem energii będą rodzime zasoby węgla kamiennego, co pozwoli na utrzymanie niezależności energetycznej kraju. Planuje się również włączenie energetyki jądrowej do miksu energetycznego Polski oraz dalszy rozwój sektora odnawialnych źródeł energii. Dotychczasowe doświadczenia i przeprowadzone badania prowadzą jednakże do wniosku, że sektor odnawialnych źródeł energii, a zwłaszcza energetyka oparta na mikroinstalacjach i aktywności prosumentów, może stać się istotnym elementem zagwarantowania bezpieczeństwa energetycznego Polski. 


\section{BibliografiA}

Barcik, J. (2008). Europejska Polityka Bezpieczeństwa i Obrony. Aspekty prawne i polityczne. Bydgoszcz: Branta. Oficyna Wydawnicza.

Braun, J. (2018). Bezpieczeństwo energetyczne jako dobro publiczne miary i czynniki wpływające na jego poziom. Studia Ekonomiczne. Zeszyty Naukowe Uniwersytetu ekonomicznego w Katowicach, 358, 23-32.

Czerpak, P. (2006). Bezpieczeństwo energetyczne. W: K. Żukrowska, M. Grącik (red.), Bezpieczeństwo międzynarodowe. Teoria i praktyka (115126). Warszawa: SGH.

Dziedzic, Z. (2011). Państwowe monopole czy w pełni liberalny rynek energii - co bardziej sprzyja bezpieczeństwu energetycznemu? Przeglad Strategiczny, 2, 351-376.

European Commission (2019). EU Energy in Figures. Pobrano z: https:// ec.europa.eu/energy/data-analysis/energy-statistical-pocketbook_ en?redir=1 (dostęp: 10.03.2020).

Jaźwiński, J. (2011). Determinanty kształtowania polskiego bezpieczeństwa gospodarczego. Wybrane aspekty. Przegląd Strategiczny, 1, 59-70.

Księżopolski, K.M. (2004). Ekonomiczne zagrożenia bezpieczeństwa państw. Metody i środki przeciwdziałania. Warszawa: Kolor Plus.

Kuciński, K. (2006). Energia w czasach kryzysu. Warszawa: Difin.

Ministerstwo Aktywów Państwowych (2019a). Liczba mikroinstalacji w Polsce wzrasta. Pobrano z: https://www.gov.pl/web/aktywa-panstwowe/liczba-mikroinstalacji-w-polsce-wzrasta (dostęp: 01.03.2020).

Ministerstwo Aktywów Państwowych (2019b). Polityka energetyczna Polski do 2040. Pobrano z: https://www.gov.pl/web/aktywa-panstwowe/ polityka-energetyczna-polski-do-2040-r-zapraszamy-do-konsultacji1 (dostęp: 01.03.2020).

Molo, B. (2013). Polityka bezpieczeństwa energetycznego Niemiec w XXI wieku. Kraków: Oficyna Wydawnicza AFM.

Nyga-Łukaszewska, H. (2016). Czy bezpieczeństwo energetyczne oznacza konkurencyjność w skali międzynarodowej?. International Business and Global Economy, 35 (1), 390-401.

Soroka, P. (2015). Bezpieczeństwo energetyczne: między teoria a praktyka. Warszawa: Elipsa.

Urząd Regulacji Energetyki (2019). Raport-zawierajacy zbiorcze informacje dotyczace energii elektrycznej wytworzonej z odnawialnego źródła energii $w$ mikroinstalacji ( $w$ tym przez prosumentów) $i$ wprowadzonej do sieci dystrybucyjnej w 2019 r. (art. 6a ustawy OZE). Pobrano z: https://www. ure.gov.pl/pl/urzad/informacje-ogolne/aktualnosci/8126,Raport-dotyczacy-energii-elektrycznej-wytworzonej-z-OZE-w-mikroinstalacji-i-wpro.html (dostęp: 15.03.2020). 
Ustawa z dnia 10 kwietnia 1997 r., Prawo energetyczne, Dz.U. nr 54, poz. 348, z późn. zm. Pobrano z: http://isap.sejm.gov.pl/DetailsServlet?id=WDU19970540348 (dostęp: 02.03.2020).

Ustawa z dnia 17 lutego 2007 r., O zapasach ropy naftowej, produktów naftowych i gazu ziemnego oraz zasadach postępowania w sytuacjach zagrożenia bezpieczeństwa paliwowego państwa i zakłóceń na rynku naftowym, Dz.U. nr 52, poz. 343, z późn. zm. Pobrano z: http://isap.sejm.gov.pl/DetailsServlet?id=WDU20070520343 (dostęp: 01.03.2020).

Ustawa z dnia 20 lutego 2015 r., o odnawialnych źródłach energii, Dz.U. 2015 nr 227, poz. 478, z późn. zm. Pobrano z: http://prawo.sejm. gov.pl/isap.nsf/download.xsp/WDU20150000478/U/D20150478Lj.pdf (dostęp: 02.03.2020).

Zięba, R. (2004). Instytucjonalizacja bezpieczeństwa europejskiego: koncepcje struktury - funkcjonowanie. Warszawa: Scholar.

Żukrowska, K. (2011). Bezpieczeństwo międzynarodowe. Przeglad aktualnego stanu. Warszawa: IUSatTAX.

\section{Copyright and License}

This article is published under the terms of the Creative Commons Attribution - NoDerivs (CC BY- ND 4.0) License http://creativecommons.org/licenses/by-nd/4.0/ 